\title{
Toxic Potentials of Nittol Detergent on Haematological Parameters of African Catfish (Clarias gariepinus) in Nigeria
}

\author{
E. A. Ivon ${ }^{1}$, G. M. Ubi ${ }^{2}$, N. A. Etangetuk ${ }^{1}$, C. O. Anyanwu ${ }^{1}$, \\ A. N. Nkang ${ }^{1}$ and A. P. Ekanem ${ }^{3}$ \\ ${ }^{1}$ Department of Science and Laboratory Technology, Faculty of Biological Science, \\ University of Calabar, Calabar, Nigeria. \\ ${ }^{2}$ Department of Genetics and Biotechnology, Faculty of Biological Sciences, \\ University of Calabar, Nigeria. \\ ${ }^{3}$ Department of Fisheries and Aquaculture, Faculty of Oceanography, University of Calabar, \\ Calabar, Nigeria.
}

Authors' contributions

This work was carried out in collaboration among all authors. Authors EAI and APE designed the study. Authors EAI, GMU and NAE performed the statistical analysis. Authors EAI, APE and COA wrote the protocol. Authors EAI and GMU wrote the first draft of the manuscript. Authors EAI, ANN and GMU managed the analyses of the study. Authors EAI and NAE managed the literature searches. All authors read and approved the final manuscript.

Article Information

DOI: $10.9734 / A R R B / 2020 / v 35 i 430212$ Editor(s):

(1) Dr. Md. Aminur Rahman, Jashore University of Science and Technology, Bangladesh.

Reviewers:

(1) S. K. Garg, CCS Haryana Agricultural University, India. (2) Pinky Kaur, Central Marine Fisheries Research Institute (ICAR), India. (3) Prem Prakash Srivastava, ICAR-Central Institute of Fisheries Education, India. Complete Peer review History: http://www.sdiarticle4.com/review-history/57597

Original Research Article

Received 20 March 2020

Accepted 26 May 2020

Published 03 June 2020

\begin{abstract}
Background: The toxic effect of Nittol detergent on the haematological parameters of the African catfish ( $C$. gariepinus) sub-adult was investigated. The experiment was conducted in triplicates forthe four treatments. Behavioral changes in fish exposed to different concentrations of Nittol detergent ranged from erratic swimming, moribund movement, jumping and lack of balance. Similar changes were not observed in the control throughout the experiment. Nittol detergent is composed of linear alkyl benzene sulphonate (LABS), sodium tripolyphosphate (STPP), sodium carbonate,
\end{abstract}


sodium sulphate, sodium per-borate and sodium silicate (perfume) as active ingredients. The fish were exposed to concentrations $1.0 \mathrm{~g} / \mathrm{L}, 2.0 \mathrm{~g} / \mathrm{L}, 3.0 \mathrm{~g} / \mathrm{L}$ and $4.0 \mathrm{~g} / \mathrm{L}$. At $1.0 \mathrm{~g} / \mathrm{l}$ concentration, the mean mortality was $80 \%$ with an initial erratic swimming.

Results: It was observed that mean mortality increased drastically with increasing Nittol Detergent concentrations. At a concentration $3.0 \mathrm{~g} / \mathrm{L}$, total mortality was observed within 72 hours of exposure preceding moribund swimming while total mortality was observed at $4.0 \mathrm{~g} / \mathrm{L}$. The concentration at which $50 \%$ of the experimental fishes were killed (LC50) was $0.9 \mathrm{~g} / \mathrm{L}$. Results from statistical analysis indicated that mortality varied significantly with concentrations as higher values recorded higher mortality rates. However, mean values showed the highest mortality (74\%) with Nittol detergent. Haematological results obtained from blood profile analysis showed various degrees of alterations and changes in values when compared to the control. The PCV of the exposed fish was $26 \%$ when compared to $27 \%$ in the control, HB was 8.9 (GDL) as against $9.0 \mathrm{Gdl}$ of the control, total WBC was $640 \times 10^{9} / \mathrm{L}$ as against $1280 \times 10^{9} / \mathrm{L}$ of the control. The RBC reading was 4.7 compared to $5.3\left(\mathrm{~mm}^{3}\right)$ of the control. For the differential counts, the lymphocyte was $80 \%$. Neutrophils were $4 \%$ and monocyte $16 \%$ compared to $62 \%, 8 \%$ and $30 \%$ of the control respectively. The results revealed a significant decrease in PCV counts for 8.0,16.0, 25.0, and 50.0ml/l concentration when compared to the control. There revealed significant decrease of haemoglobin count for $8.0 \mathrm{ml} / \mathrm{l}$ group $(p>0.05)$ and significant decrease for $16.0 \mathrm{ml} / \mathrm{l}, 25.0 \mathrm{ml} / \mathrm{l}$ and $50.0 \mathrm{ml} / \mathrm{l}$ groups $(p<0.05)$, when compared to the control. The results showed insignificant decrease of RBC count for $1.0 \mathrm{~g} / \mathrm{l}(\mathrm{p}>0.05)$ and a significant decrease for the 2.0, 3.0 and $4.0 \mathrm{~g} / \mathrm{l}$ groups $(p<0.05)$, compared to the control. This means that as the toxicant concentration increased, the fish red blood count decreased the more. This further implies that at higher concentration of, RBC reduces correspondingly. Lymphocytes, monocytes, and neutrophils in the control set showed (apparently normal cell after) hematoxylin and eosin staining. Differential blood samples exposed to various concentrations of Nittol Detergent showed denatured cells, haemolysis and blood cell shrinkage.

Conclusion: It was therefore concluded that Nittol Detergent has significant toxic effect on the haematological parameters of $C$. gariepinus and recommended the control disposal of this detergent into aquatic bodies to reduce the negative impact on the blood quality of aquatic organisms.

Keywords: Detergent; aquatic pollution; blood quality; Clarias gariepinus.

\section{INTRODUCTION}

African catfish (Clarias gariepinus) are sharp tooth catfish, eel-like in nature, usually dark gray or black with coloration on the back, fading to a white belly. In Africa, thecatfish have been reported as being second in size only to the Vundu of the Zambesian waters [1,2]. It has an average adult length of $1.0-1.5 \mathrm{~m}$. It reaches a maximum length of $1.7 \mathrm{~m}$ and can weigh up to $60 \mathrm{~kg}$. These fish have slender bodies, flat bony heads, notably flatter in the genus Silirus, and broad terminate mouths with four pairs of barbels. They also have large accessory breathing organs composed of modified gill arches, and only the pectoral fins have spines. African catfish is nocturnal fish like many other catfish. It feeds on both living and dead animal matter. Because of its wide mouth, it is able to swallow relatively large prey whole. It is able to crawl on dry ground to escape drying pools and it is also able to survive in shallow mud for long periods of time in between rainy seasons [3,4]. It spawns around inundated areas of river, lakes and streams mostly at night [5]. One of the reasons for the choice of this genus of fish for this research work is that it is considered as an aquatic biomarker [6-9]. Other reasons for the choice of this fish species includes its hardiness and ability to tolerate adverse water quality conditions, its ability to grow fast and feed on a large variety of agriculture by-products and its ability to tolerate difficult conditions in captivity [10].

Studies have shown that physiological variables, including red blood cells (RBCs) and hemoglobin content in fish exposed to pollutants and toxicants changed with time. Most chemicals exhibit deleterious effects on the aquatic environment if not properly handled or controlled. Industrial products beneficial to humans can also pose serious threats to man and the entire environment [1113,9]. Most of the commonly used industrial products in Calabar, Nigeria include detergents, fertilizers, kerosene, and a host of others [14]. Pollution is a global menace that affects all ecological habitats. It is the introduction of foreign toxic substances capable 
of causing harm to man and the entire environment $[15,16]$.

Pollution occurs either on land, air or water. Man depends heavily on water for domestic, industrial, and agricultural uses. Poor water quality means water pollution [17]. No nation is completely free from the global menace of water pollution [18]. This era of globalization and industrialization has sky rocketed the rates of aquatic pollution due to the increasing volume of industrial, and domestic effluents that find their way into fresh water and marine habitats, thus altering the balance of these ecosystems [19,20].

Unrestricted municipal sewage discharge into water bodies, effluents from chemical industries and direct dumping of biodegradable and nonbiodegradable wastes are other sources of water pollution. Apparently, human and ecological disorders experienced in industrial settlements as a result of improper disposal of chemicals such as detergent effluents are alarming [21].

In developing countries like Nigeria, only a few chemicals have been ecologically tested for safety in spite of their environmental impacts [22]. Every ocean and every continent, from the tropics to the once-pristine polar regions is contaminated [23,24]. The effects of these activities are often outrageous with corresponding immediate or later consequences to both direct and indirect dependents of these water bodies [25]. Strict government legislation and heavy penalties have not in any way changed these negative trends of indiscriminate disposal of chemicals into our water bodies. Detergents are one of the most toxic pollutants we have in the world today inflicting so much damage to the environment and the organisms thereon, especially those in the aquatic environment $[26,27,9]$.

Detergents apart from altering water quality and chemistry, inflict heavy and sometimes fatal damages to aquatic organisms and their dependents, [28]. However, fish habitats are contaminated mostly through a number of aquatic pollutants [29].Detergents are widely used in both industrial and domestic premises and are mostly used in washing vehicles, clothes, carpets, cooking utensils, floors, cutleries, and other dirty objects [30]. Most pollutants including detergents, find their way into water bodies through surface run-off, improper sewage discharge, and direct discharge during washing and bathing in streams, rivers, and other water bodies [31]. Detergents also show tendencies to unleash poisonous effects in all types of aquatic life if found in sufficient quantities and these includes some biodegradable detergents like Nittol Detergent. [32]. Most fishes will die when detergent concentration approaches 15 parts per million (15 ppm) [33,9].

Detergent concentration as low as 5 ppm will kill fish eggs [34]. As a result of the enormous adverse effects detergents have on the aquatic environment, they are listed among the major aquatic pollutants in the world [34]. Their effects on the environment outweighs any other advantage(s). Its affordability and high efficiency in removing stains from objects makes a greater number of people prefer using it in Nigeria [35]. One of the aquatic organisms often affected drastically by these chemical pollutants called detergent in the African catfish [36]. Phosphates are used in detergents to soften hard water and help suspend dirt in water [37]. Apart from being used for washing and removal of stubborn dirts and stains, detergents have been found to be very effective for clean up oil spills. But studies have shown that detergents often used to clean up oil spills appear more toxic to coral reefs than the oil itself [38].

Detergents are organic compounds, which have both polar and non-polar characteristics. They tend to exist at phase boundaries, where they are associated with both polar and non-polar media. Detergents are of three types: ammonic, cationic and nonionic. Anionic and cationic have permanent negative or positive charges attached to non-polar (hydrophobic) $\mathrm{C}-\mathrm{C}$ chains. Nonionic detergents have no such permanent charge; instead, they have a number of atoms that are weakly electropositive or electronegative. This is due to detergents with different characteristics: phosphate detergents and surfactant detergents [39].

Detergents that contain phosphate are highly caustic and surfactant detergents are very toxic. The differences are that surfactant detergents are used to enhance the wetting, foaming, dispersing, and emulsifying properties of detergents, [40]. Nittol detergent was chosen for this study. Nittol detergent is composed of linear alkyl benzene sulphonate (LABS), sodium tripolyphosphate (STPP), sodium carbonate, sodium sulphate, sodium perborate and sodium silicate (perfume) as active ingredients. It is a new product of less than two years in the market 
as at the time of commencing this research [41]. It is in view of the high patronage and usage of this highly toxic detergent that this research was tailored to unveil the haematological parameters effect associated with the indiscriminate pollution of aquatic environments with this chemical pollutant.

\section{MATERIALS AND METHODS}

\subsection{Study Location}

The University of Calabar is located between the Calabar municipality and Calabar south local government areas of the Cross River State, Nigeria. It is bounded to the east by the Great Quo River, Calabar is the capital of Cross River State, Nigeria. It is located geographically at 40 57" North 80191 0' East. Cross River State is one of the States in the Niger Delta, South South Region of Nigeria. The State shares a maritime boundary with Cameroon in the east, Akwa lbom State in the South, Abia and Ebonyi States in the West and Benue State in the North. It is geographically located at $5^{\circ} 45^{1} \mathrm{~N}, \quad 8^{\circ} 30^{1} \mathrm{E}$ $15^{\circ} 75^{1} \mathrm{~N}, 8.5^{\circ} \mathrm{E}$, [42]. The State according to National Population Commission (NPC) [42] has a population of 3.2 million people with a land mass of $20,156 \mathrm{~km}^{2}(7,782 \mathrm{sqm})$.

The temperature in Calabar ranges from 21.05 to $33.15^{\circ} \mathrm{C}$. It is often at its maximum within the months of January to April. Rainfall in Calabar is not stable and consistent as it rains throughout the year. It rains more between the months of April and November with the peak between May and October. Calabar has an average annual precipitation of $2718 \mathrm{~mm}$.

Calabar is situated in the tropical rain forest with mangroves and swamps in some areas. It is described as 'clean and green State'. Most of the original vegetation in the study area has been replaced as a result of agriculture, industrial and building activities [42].

Activities in rural areas are mainly agriculture and petty trading, urban areas are characterized by heavy commercial activities, industrialization and tertiary education. Fish farming is also one of the major human activities in both rural and urban areas of the study location [42].

\subsection{The Fish Farm}

The University of Calabar Fish Farm is located approximately $1 \mathrm{~km}$ away from the research laboratory. The fish farm harbors various sizes and species of fishes ranging from fry, fingerlings sub adults and adults (plate 1). This research was carried out in the Fish Pathology Laboratory of the Faculty of Oceanography, University of Calabar. Collection of samples and gathering of materials were preceded by a thorough reconnaissance survey.

\subsection{Sources of the Pollutants}

The Nittol detergent was purchased from Victory stores, Satellite town, Calabar in Cross River State, Calabar, Nigeria.

\subsection{Field Investigation}

A trip was taken to the university of Calabar fish farm to ascertain the availability of African catfish (Clarias gariepinus) subadults. After confirming the availability, the desired quantity was booked for. Similarly, the chosen Nittol Detergent toxicant was sorted in a shop in Calabar.

\subsubsection{Collection and transportation of the study fish}

A total of 600 C. gariepinus sub adults with a mean weight of $8.5 \pm 0.2 \mathrm{~g}$ were purchased from the University of Calabar fish farm. Samples were carefully collected and transferred into a plastic container and transported to the Faculty of Oceanography, University of Calabar, the Cross River State, Nigeria. The study fishes were transported to the laboratory in transparent plastic containers by car to the laboratory which is about a five minute drive from the fish farm.

\subsubsection{Laboratory studies}

A whole day was used in arrange the laboratory. Unwanted and obstructive materials were removed and the needed aquaria were thoroughly washed and dried.

\subsection{Acclimation of Study Specimens}

The sub-adults fish were transferred into a laboratory aquarium $\left(80 \times 30 \times 30 \mathrm{~cm}^{3}\right)$ and allowed to acclimatize in the holding tank under laboratory conditions for one week at a temperature of $30.02 \pm 0.09^{\circ} \mathrm{C}$ and $\mathrm{a} \mathrm{pH}$ of 8 , and were fed once daily with commercial feed (copens) at $5 \%$ of their body weight. The unconsumed feeds and faeces were removed from the holding tank and the water in the tank was changed every 24 hours as recommended by Reish and Oshida [43]. 


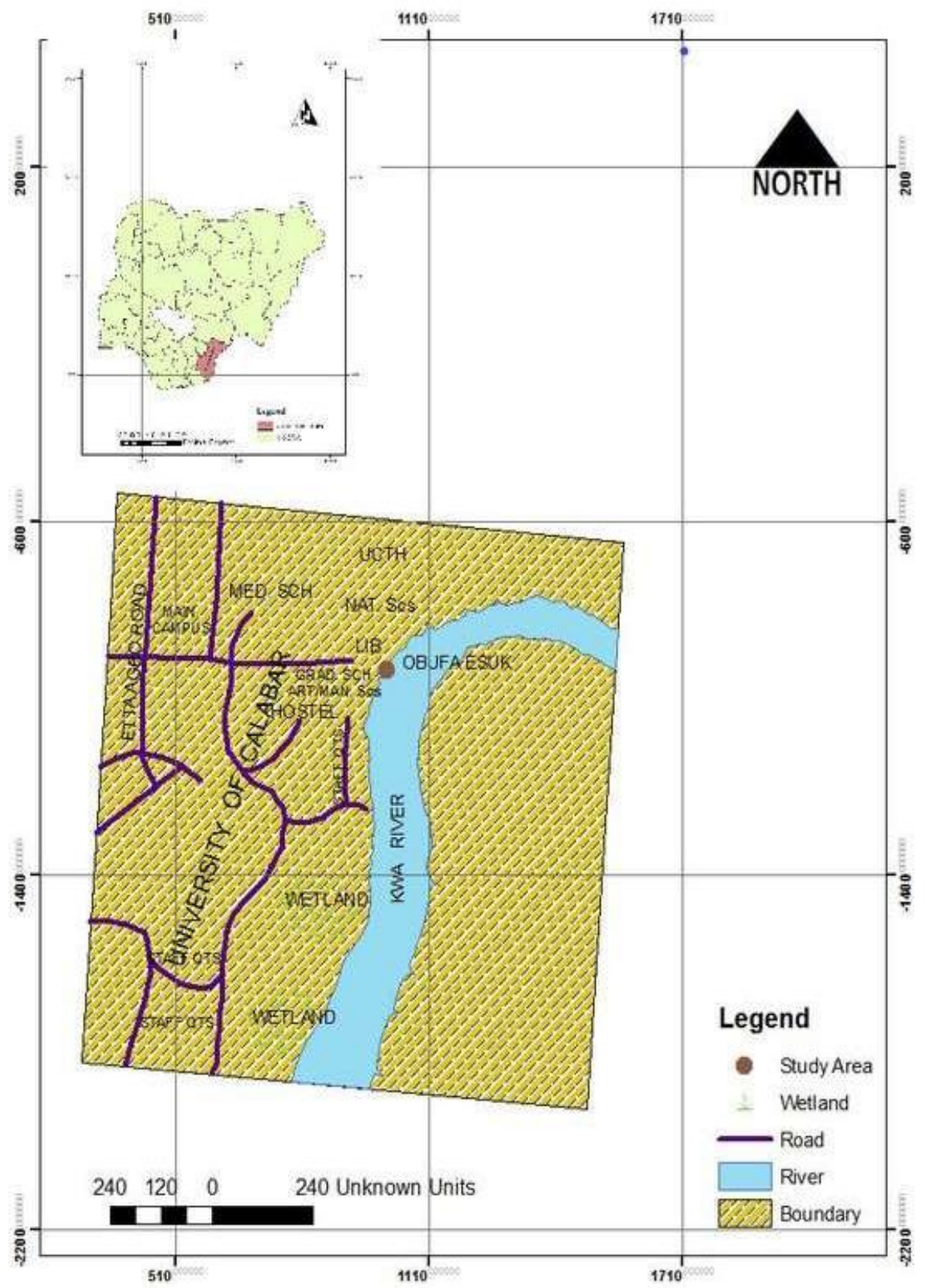

Map 1. Map of the University of Calabar showing the fish farm

\subsection{Toxicant Used}

The toxicant selected and used for the experiment was Nittol Detergent.

\subsection{Fish Stocking}

Ten sub-adults were carefully introduced to each of the plastic aquaria containing the measured toxicant and another ten (10) introduced to the control aquaria (plate 5) using a hand sieve. This procedure was repeated for all experiments.

\subsection{Range Finding Tests}

Series of range finding tests were conducted using the toxicants and the sub-adults fish to determine the concentration boundaries before the actual experiment. 


\subsection{Detergent Toxicity Experiments}

The experiment was carried out in triplicate for four treatments i.e. $0.00 \mathrm{~g} / \mathrm{L}$ (control), $1.0 \mathrm{~g} / \mathrm{L}, 2.0$ $\mathrm{g} / \mathrm{L}, 3.0 \mathrm{~g} / \mathrm{L}$ and $4.0 \mathrm{~g} / \mathrm{L}$. Ten (10) sub adults of C. gariepinus were stocked in each of the four glass aquaria $\left(25 \times 15.5 \times 15.5 \mathrm{~cm}^{3}\right)$ in triplicate for the experiment. The experiment was monitored periodically; observation and responses were taken at intervals of $24,48,72$ and 96 hours respectively.

\subsection{Haematological Studies (Blood Profile)}

Collection of blood samples from the treated and control fishes were obtained by inserting a needle directly from the anterior part of the anal fin about 2-5 $\mathrm{mm}$ behind the genital papilla to draw the desired amount of blood [44]. Blood profiles such as Red Blood Cell count (RBC), White Blood Cell count (WBC), Blood Differentials, Hemoglobin, (HB), and Packed Cell Volume (PCV) of the treated fishes and control were estimated after exposure of the fish to the Nittol Detergent toxicity. The Haematological indices were carried out at the Hematology Department of the University of Calabar Teaching Hospital, Calabar, Cross River, Nigeria.
Blood samples were collected from the fish into anticoagulant (EDTA) bottles and rocked gently to ensure proper mixing while avoiding haemolysis according to [44].

\subsection{Statistical Analysis}

Data obtained were analyzed using analysis of variances (ANOVA) for significant difference $(p<0.05)$ at the $95 \%$ confidence limit. Significant treatment means were separated using Fischer's' least significant difference (LSD) test.

\section{RESULTS}

Results of the effect of Nittol detergent on the mortality of African catfish (Clarias gariepinus) as presented in Fig. 1 shows that at $1.0 \mathrm{~g} / \mathrm{l}$ concentration, the mean mortality was $80 \%$ with an initial erratic swimming. It was observed that mean mortality increased drastically with an increasing concentration of the Nittol. At a concentration of $3.0 \mathrm{~g} / \mathrm{L}$, total mortality was observed within 72 hours of exposure preceding moribund swimming while total mortality was observed at $4.0 \mathrm{~g} / \mathrm{L}$. The concentration at which $50 \%$ of the treated fish population was killed (LC50) at $0.9 \mathrm{~g} / \mathrm{L}$.

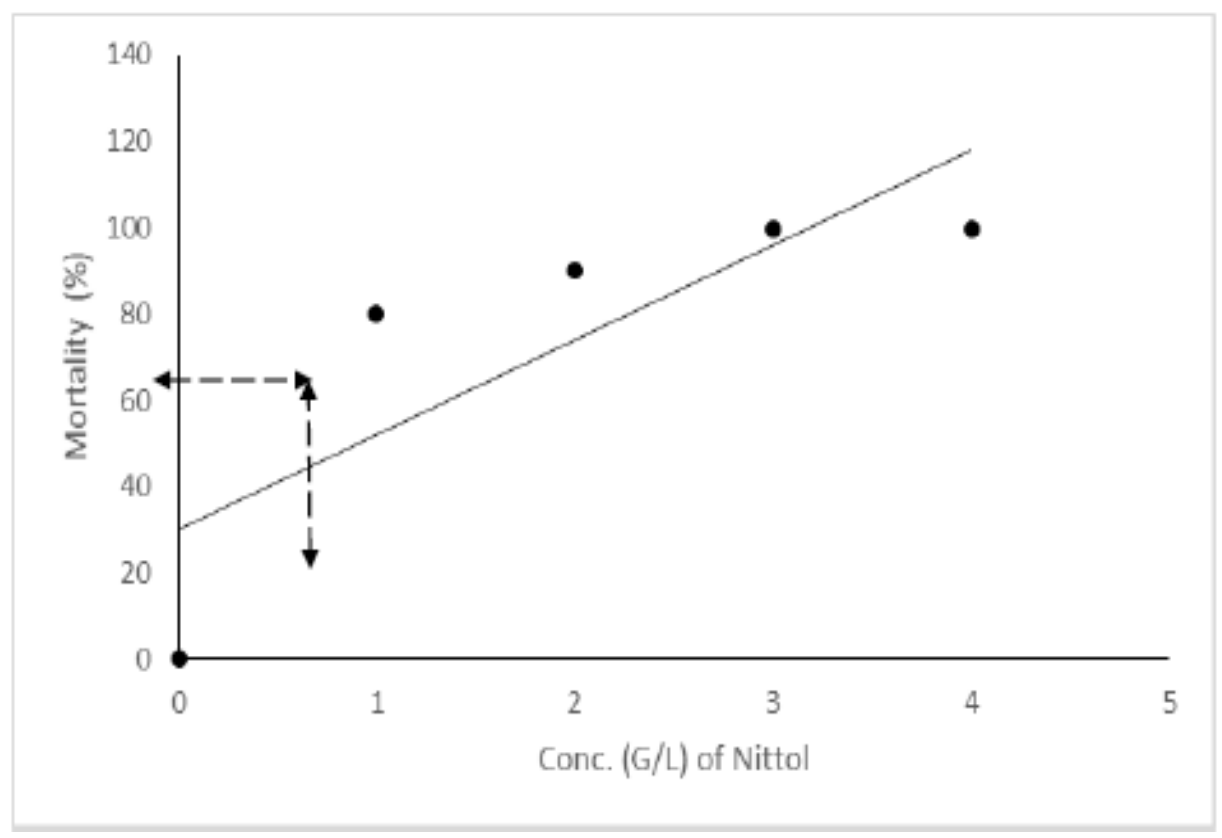

Fig. 1. Graph of concentrations of $1.0,2.0,3.0$ and $4.0 \mathrm{~g} / \mathrm{l}$ against mortality $L C_{50}=0.9 \mathrm{~g} / \mathrm{l}$ of Nittol detergent 
The results of various haematological parameters showed variations/alterations in treated and control blood samples as shown in Table 1. The PCV of the exposed fish was $26 \%$ when compared to the control at $27 \%$, HB was 8.9 (GDL) as against $9.0 \mathrm{GdL}$ of the control, total WBC was $640 \times 10^{9} / \mathrm{L}$ as against $1280 \times 10^{9} / \mathrm{L}$ of the control. The $\mathrm{RBC}$ reading was 4.7 compared to $5.3\left(\mathrm{~mm}^{3}\right)$ of the control. For the differential counts, lymphocyte was $80 \%$. Neutrophils were $4 \%$ and monocyte $16 \%$ compared to $62 \%$, $8 \%$ and $30 \%$ of the control respectively. These alterations may not be unconnected with the effects of the pollutant (Nittol detergent) on the haematological parameters of the catfishes (Table 1).

Result from Fig. 2 revealed significant decrease of haemoglobin count for $8.0 \mathrm{ml} / /$ group $(p>0.05)$ and significant decrease for $16.0 \mathrm{ml} / \mathrm{l}, 25.0 \mathrm{ml} / \mathrm{l}$ and $50.0 \mathrm{ml} / \mathrm{l}$ groups $(\mathrm{p}<0.05)$ when compared to the control. This implies that as the concentration increased, haemoglobin levels dropped significantly due to the toxicant effect. Results showed a significant decrease in white blood cell count at all concentrations when compared to the control.
The results in Fig. 3 show that all the toxicant concentrations caused significant decreases in the WBC counts.

The result in Fig. 4 reveals a significant decrease in PCV counts at 8.0,16.0, 25.0 and $50.0 \mathrm{ml} / \mathrm{l}$ concentrations as compared to the control. The implication is that the PCV of the exposed fish decreased significantly in all the concentrations.

Fig. 5 shows a significant increase in lymphocyte count for the 1.0, 2.0, 3.0 and $4.0 \mathrm{~g} / \mathrm{l}$ groups $(p<0.05)$ as compared to the control. This suggests that the toxicant (Nittol detergent) triggered an increase in the lymphocyte counts in C. gariepinus.

Fig. 6 shows insignificant decrease of RBC count for $1.0 \mathrm{~g} / \mathrm{l}(\mathrm{p}>0.05)$ and a significant decrease for the 2.0, 3.0 and $4.0 \mathrm{~g} / \mathrm{l}$ groups $(p<0.05)$ as compared to the control. This means that with the increase in concentration of toxicant, the red blood count in treated fish decreases. This further implies that at higher the concentration of toxicant, $\mathrm{RBC}$ reduces correspondingly.

Table 1. Effect of toxicant (Nittol detergent) on the haematology of Clarias gariepinus

\begin{tabular}{|c|c|c|c|c|c|c|}
\hline Sample & $\begin{array}{l}\text { PCV } \\
\text { (\%) }\end{array}$ & $\begin{array}{l}\text { HB } \\
\text { (gdl) }\end{array}$ & $\begin{array}{l}\text { Total } \\
\text { WBC }\end{array}$ & $\begin{array}{l}\text { Differential } \\
\text { count }(\%)\end{array}$ & $\begin{array}{l}\text { RBC } \\
\left(M^{3}\right)\end{array}$ & Remarks \\
\hline Control & 27 & 9.0 & $1280 \times 10^{9} / L$ & $\begin{array}{l}\mathrm{L}(62) \\
\mathrm{N}(8) \\
\mathrm{M}(30) \\
\text { *Mature } \\
\text { Nucleated cells }\end{array}$ & 5.3 & Normal \\
\hline Nittol Detergent & 26 & 8.7 & $64 \times 10^{9} / \mathrm{L}$ & $\begin{array}{l}\mathrm{L}(80) \\
\mathrm{N}(4) \\
\mathrm{M}(16)\end{array}$ & 4.7 & $\begin{array}{l}\text { Alteration in } \\
\text { blood profile }\end{array}$ \\
\hline
\end{tabular}

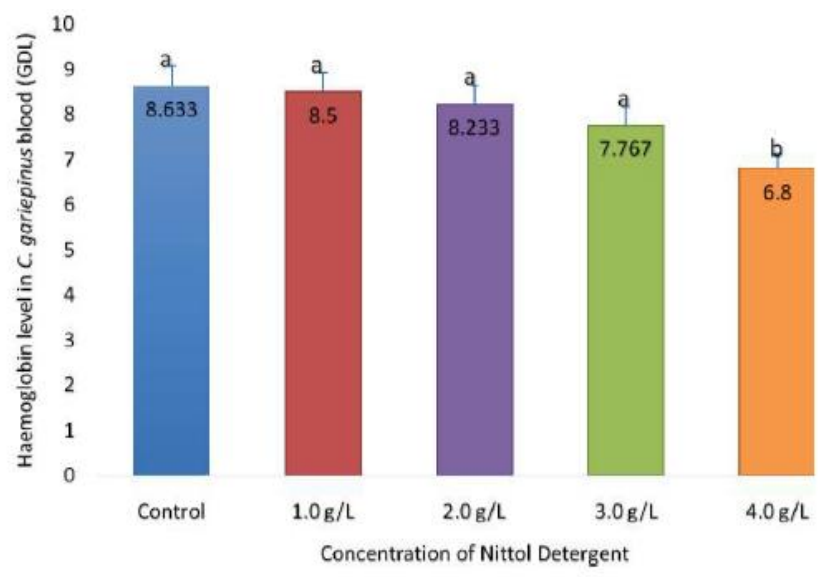

Fig. 2. Insignificant decrease in haemoglobin $(\mathrm{Hb})$ counts in $1.0,2.0$ and $3.0 \mathrm{~g} / \mathrm{L}$ Group ( $p>0.05)$ and significant decrease for the $4.0 \mathrm{~g} / \mathrm{L}$ groups $(p<0.05)$ as compared to the control 


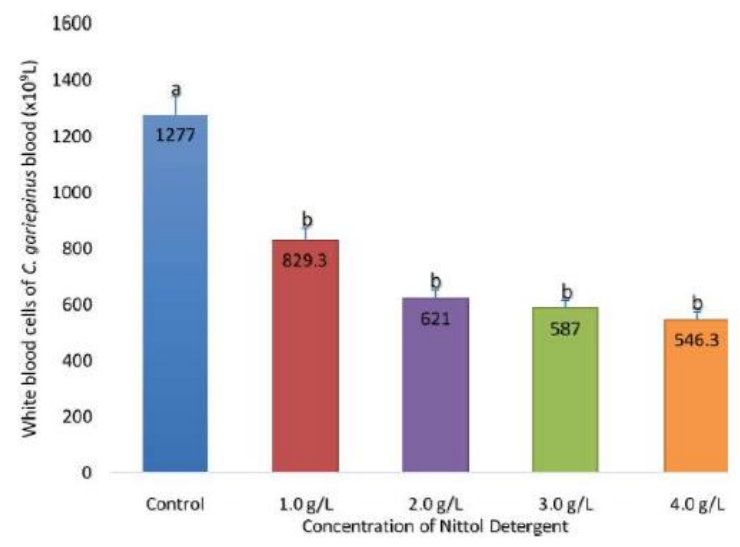

Fig. 3. Significant decrease in the white blood cell counts at 1.0, 2.0, 3.0 and $4.0 \mathrm{~g} / \mathrm{L}$ concentrations of Nittol detergent $(p<0.05)$ as compared to the control

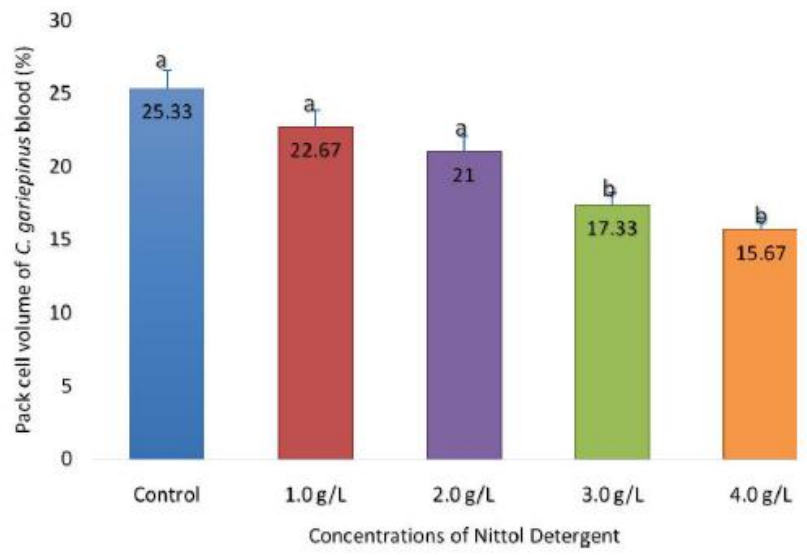

Fig. 4. Insignificant decrease in pack cell volume for 1.0 and $2.0 \mathrm{~g} / \mathrm{L}$ group $(p>0.05)$ and a significant decrease in 3.0 and $4.0 \mathrm{~g} / \mathrm{L}$ groups $(P<0.05)$ as compared to the control

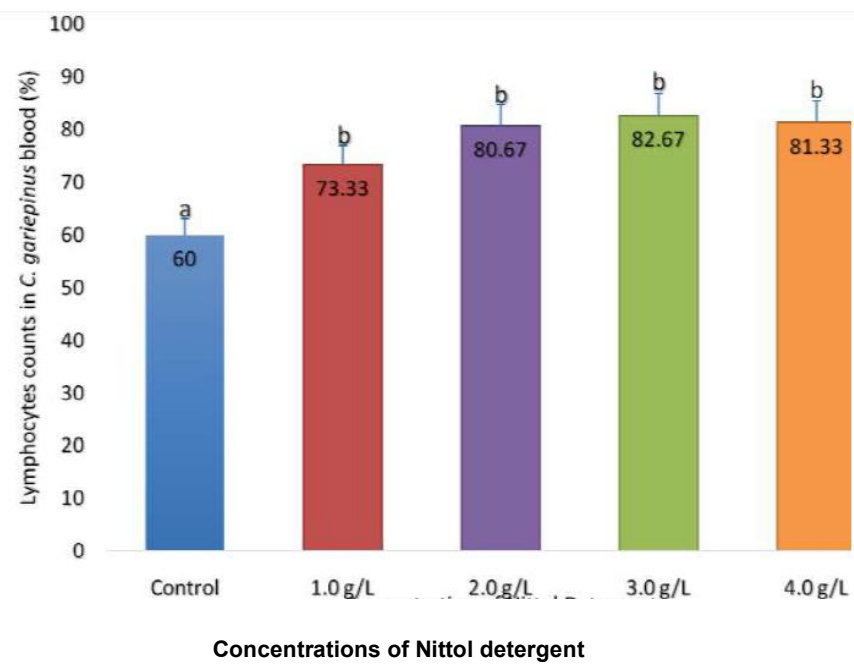


Fig. 5. Significant increase in lymphocyte counts at 1.0, 2.0, 3.0 and $4.0 \mathrm{~g} / \mathrm{L}$ groups $(p<0.05)$ as compared to the control
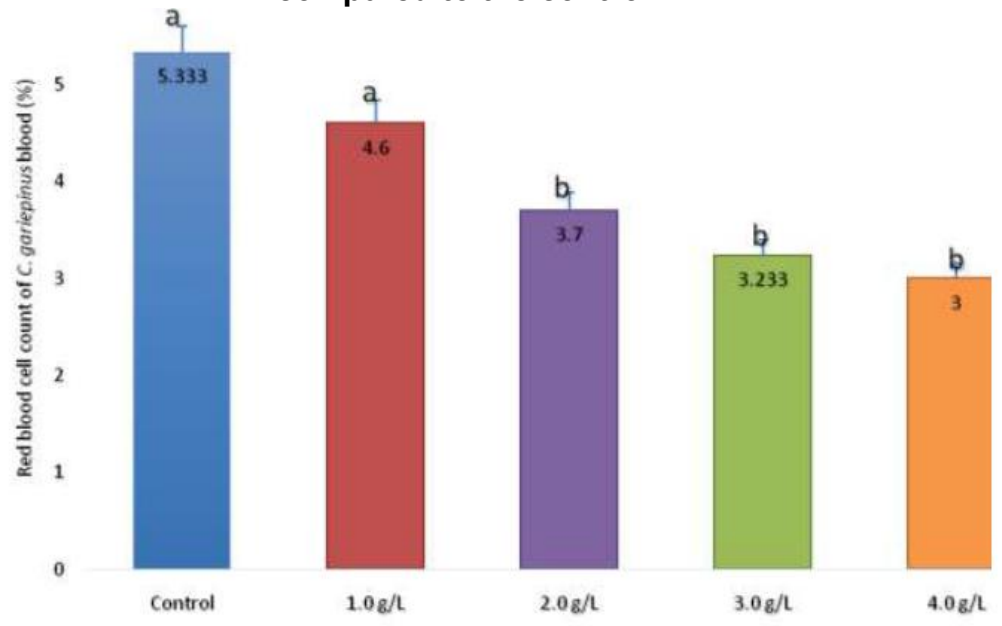

Concentration of Nittol Detergent

Fig. 6. Insignificant decrease in red blood cell counts at $1.0 \mathrm{~g} / \mathrm{L}$ group $(p>0.05)$ and a significant decrease at 2.0,3.0 and $4.0 \mathrm{~g} / \mathrm{L}$ grousp $(p<0.05)$ as compared to the control

There was an insignificant decrease in neutrophil counts for the $100 \mathrm{~g} / \mathrm{l}$ group $(p>0.05)$ and a significant decrease for the 2.0, 3.0 and $4.0 \mathrm{~g} / \mathrm{l}$ group $(p<0.05)$ when compared to the control. This implies that neutrophil count decreased significantly as concentration increased as shown in Fig. 7, when compared to the control.

Fig. 8 shows a significant decrease in the monocyte counts for the 1.0, 2.0, 3.0 and $4.0 \mathrm{~g} / \mathrm{l}$ groups $(\mathrm{p}<0.05)$ as compared to the control. This shows that as the toxicant (Nittol detergent) concentration increases, the monocyte count significantly reduces the more. This may not be unconnected with the effect of this toxicant on $C$. gariepinus.

Lymphocytes, monocytes and neutrophils in the control group showed normal cells appearance when stained with hematoxylin and eosin stain. Differential blood samples exposed to various concentrations of Nittol detergent showed denatured cells, haemolysis and cell shrinkage (Plates 1 - 5). Plate 1 shows normal monocytes and lymphocytes in the control. Plate 2 shows denatured monocytes in $1.0 \mathrm{~g} / \mathrm{l}$ of Nittol detergent. Plate 3 show haemolysed RBC in 2.0 $\mathrm{g} / \mathrm{l}$ Nittol concentration and Plates 4 and 5 showed denatured neutrophils in $3.0 \mathrm{~g} / \mathrm{l}$ and 4.0 g/l concentration, respectively.
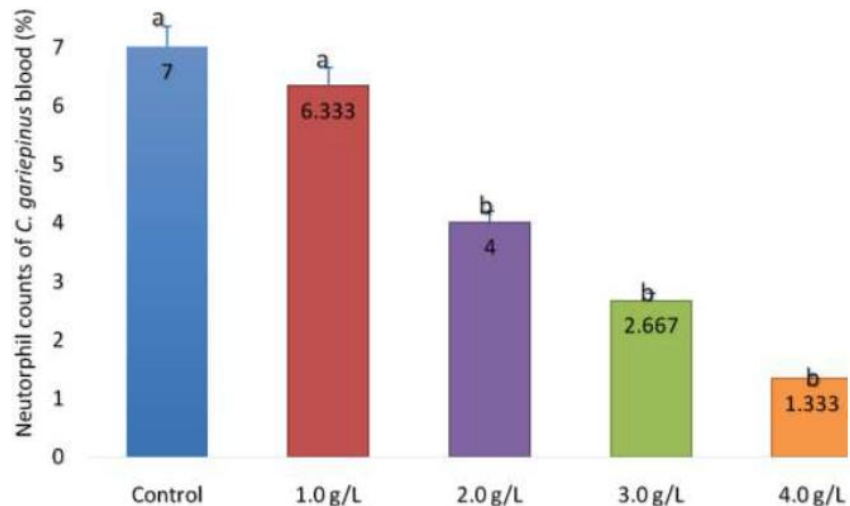

Concentration of Nittol Detergent

Fig. 7. Insignificant decrease of neutrophil counts for $1.0 \mathrm{~g} / \mathrm{L}$ group $(p>0.05)$ and a significant decrease for the $2.0,3.0$ and $4.0 \mathrm{~g} / \mathrm{L}$ groups $(p<0.05)$ as compared to the control 


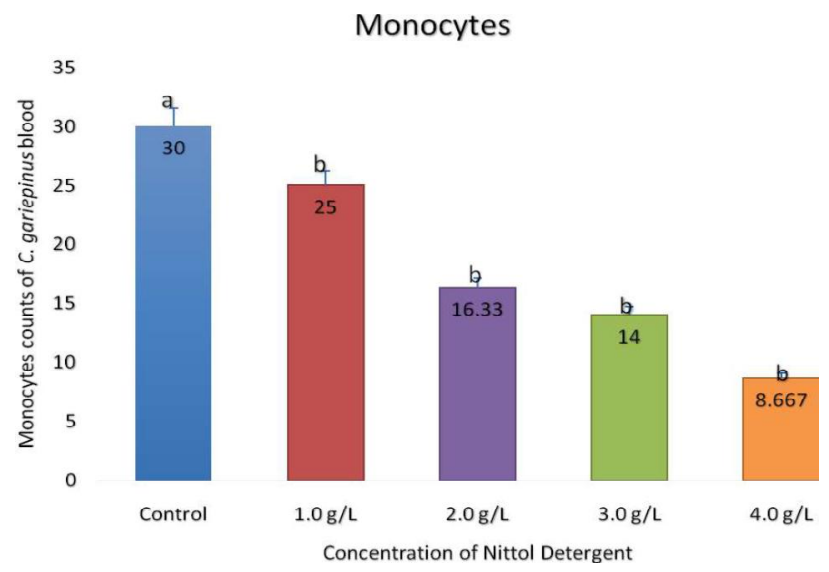

Fig. 8. Significant decrease in monocyte counts for the 1.0, 2.0, 3.0and $4.0 \mathrm{~g} / \mathrm{L}$ groups $(p<0.05)$ as compared to the control

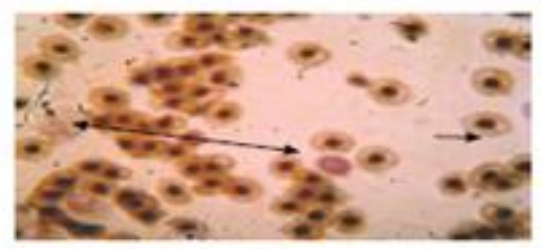

Plate 1: Lymphocytes and monocytes in control
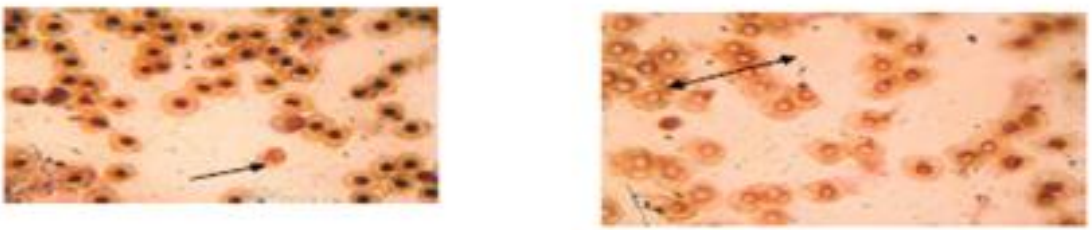

Plate 2: Monocytes in $1.0 \mathrm{~g} /$ Nittol detergent

Plate 3: Haemolysed RBC (arrow) in $2.0 \mathrm{~g} / 1$ Nittol detergent

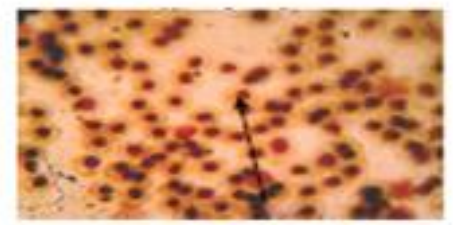

Plate 4: Neutrophil in 3.0 g/ Nittal detergent (x10)

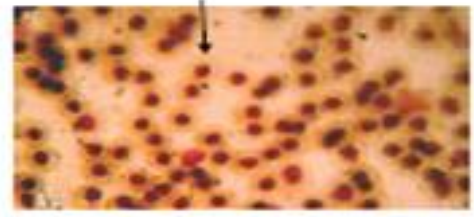

Plate 5: Neutrophil (arrow) in 4.0 g/1Nittol detergent (x 10) 


\subsection{Results of Bioassay Analysis at Various Concentrations of the Toxicant (Nittol Detergent)}

Analysis and comparison of levels of PCV (\%) between control and the different concentrations of toxicants at the end of the $96 \mathrm{~h}$ bioassay showed nittol detergent toxicity at $4.0 \mathrm{~g} / \mathrm{l}$ have highest PCV levels.

Comparison of the levels of $\mathrm{Hb}(\mathrm{GdL})$ between the control and treated groups at the end of the 96 hour bioassay showed C. gariepinus exposed to Nittol detergent at $4.0 \mathrm{~g} / \mathrm{l}$ have high value. Comparison of total WBC (x107) between control and different treatment groups at the end of 96 hour bioassay revealed that $4.0 \mathrm{~g} / \mathrm{l}$ had the highest impact on WBC counts.

Comparison of total RBC $\left(\mathrm{mm}^{3}\right)$ between control and the different treatment groups at the end of 96 hours exposure showed $C$. gariepinus exposed to $4.0 \mathrm{~g} / \mathrm{l}$ had the highest reduction in total RBC counts.

Comparison of differential count (\%) between control and different treatment groups at the end of 96 hours bioassay showed that at $4.0 \mathrm{~g} / \mathrm{l}$ of Nittol detergent toxicant triggered a rise in the lymphocytes levels even above the control. Monocytes counts ranged from 8.664 to 30 for those exposed to all the different concentrations were not altered when compared to the control. There was however minor changes in the counts of neutrophils for $C$. gariepinus exposed to Nittol detergent.

\section{DISCUSSION}

At $1.0 \mathrm{~g} / \mathrm{l}$ concentration, the mean mortality was $80 \%$ with an initial erratic swimming. It was observed that mean mortality increased drastically with an increase in the concentration of the toxicant (Nittol). At a concentration of 3.0 $\mathrm{g} / \mathrm{L}, 90 \%$ mortality was observed within 72 hours of exposure preceding moribund swimming while $100 \%$ mortality was observed at $4.0 \mathrm{~g} / \mathrm{L}$. The lethal concentration at which $50 \%$ of the treated fish was killed (LC50) was $0.9 \mathrm{~g} / \mathrm{L}$. Results from statistical analysis indicated that mortality varied significantly with concentrations as higher values recorded the high mortality rates. This result is in agreement with the findings and reports of [44].

However, mean values showed highest mortality $(74 \%)$ with Nittol detergent. Similarly, hematological profiles like Packed Cell Volume (PCV) Haemoglobin ( $\mathrm{Hb})$, Total White Blood cell
Count (WBC) and Red Blood Count were conducted on the control and exposed/treated fish. The results revealed severe alterations in haematological parameters of the treated fishes to various degrees when compared with the control (Table 1), thus corroborating with the findings and assertions of [45].

The PVC and HB results indicated a slight but significant decrease with the control figures PCV $26 \%, \mathrm{Hb} 8.7 \mathrm{~g} / \mathrm{dL}$, and RBC $5.3 \mathrm{~mm}$. This decrease in the values of haematological parameters like PCV and HB can be linked to hemolysis occasioned by damage to hematopoietic tissues in the kidneys and aggregation at the gills thereby causing a decrease in the number of circulating cells of stressed fish as similarly recorded by [46].

A low WBC indicates obstruction in the bone marrow function by the toxicant or other stressors as corroborated by [47]. The differential blood count showed an increase in Lymphocyte, (Lymphocytosis), decrease in Neutrophils (Neutropenia) and decrease in monocyte (monocytopenia) readings when compared with the control, whereas the low monocyte and neutrophil readings may not be unconnected with contact with strange of white blood cells in fish may and could also be due to several factors like chemotherapy, infections, anaemia and the environment as recorded by [48].

Similarly, hematological profiles like packed cell volume (PCV) Haemoglobin ( $\mathrm{Hb})$, Total White Blood cell Count (WBC) and Red Blood Count were conducted on the control and exposed fish. The results shows variations in the response of the treated fishes to the toxicant at various degrees when compared with the control (Table 1 ), this corroborates the reports of [49].

The PVC and $\mathrm{Hb}$ results indicated a slight but a significant decrease with the control figures. PCV of $26 \%, \mathrm{Hb} 8.7 \mathrm{~g} / \mathrm{dL}$ and RBC $5.3 \mathrm{~mm}^{3}$. This decrease in the values of haematological parameters like PCV and $\mathrm{Hb}$ can be linked to hemolysis occasioned by damage to hematopoietic tissues in the kidneys and aggregation at the gills thereby causing a decrease in the number of circulating cells of stressed fish as similarly recorded by $[50,51,52]$.

Comparison of PCV, $\mathrm{Hb}$ and $\mathrm{RBC}$ with the control showed decreased values and readings. This could have been caused by anaemia and haemolysis which agrees with similar finding [53]. 
A comparison of differential count (\%) between control and kerosene toxicant revealed elevated levels of lymphocytes (lymphocytosis) and a decrease in monocyte count. This finding agrees with $[54,55,56]$. A comparison of total RBC $\left(\mathrm{mm}^{3}\right)$ of the exposed fish with the control showed a drastic decrease in the RBC count.

The toxicants had showed no significant impact on the neutrophils. According to $[57,58]$, the primary function of neutrophil is to fight bacteria, and viruses.. The toxicant does not fall under any of these categories. Thus, the reason they are not altered. Intoxication with Nitrite containing compounds may result to anaemia following oxidation of haemoglobin to methemoglobin $[59,60]$.

\section{CONCLUSION}

Haematological indices of the blood samples of the catfishes exposed to Nittol Detergent revealed serious obstruction of the Red blood cells, Pack Cell volume, white blood cells, blood differentials, neutrophils and leucocytes cells. In all, a two way Analysis of variance on effect of toxicant with different concentrations on mortality at the end of $96 \mathrm{hr}$ bioassay showed (a) significantly difference at $\mathrm{P}<0.05$ while (b) not significantly different at $\mathrm{P}>0.05$ for the control. The study reveals significant decrease of $\mathrm{PCV}$ counts for 8.0, 16.0, 25.0 and $50.0 \mathrm{ml} / \mathrm{l}$ concentration when compared to the control. There was significant decrease in haemoglobin count for $8.0 \mathrm{ml} / \mathrm{l}$ group $(\mathrm{p}>0.05)$ and significant decrease for $16.0 \mathrm{ml} / \mathrm{l}, 25.0 \mathrm{ml} / \mathrm{l}$ and $50.0 \mathrm{ml} / \mathrm{l}$ group $(p<0.05)$ when compared to the control. The study shows insignificant decrease of RBC count for $1.0 \mathrm{~g} / \mathrm{l} \quad(p>0.05)$ and a significant decrease for $2.0,3.0$ and $4.0 \mathrm{~g} / \mathrm{l}$ group $(p<0.05)$ compared to the control. This means that as the toxicant concentration increased, the fish red blood count decreased the more. The study further revealed that at higher concentration of the toxicant, RBC reduces correspondingly. Lymphocytes, monocytes and neutrophils in the control showed normal cells appearance when stained with hematoxylin and eosin stains. Differential blood samples exposed to various concentration of Nittol Detergent showed denatured cells, haemolysis and cell shrinkage. It was therefore concluded that Nittol Detergent causes significant and negative effect on $C$. gariepinus and thus recommended the efficient control and disposal of this detergent into aquatic bodies to reduce the negative impact on the blood quality of aquatic organisms.

\section{DISCLAIMER}

The products used for this research are commonly and predominantly use products in our area of research and country. There is absolutely no conflict of interest between the authors and producers of the products because we do not intend to use these products as an avenue for any litigation but for the advancement of knowledge. Also, the research was not funded by the producing company rather it was funded by personal efforts of the authors.

\section{COMPETING INTERESTS}

Authors have declared that no competing interests exist.

\section{REFERENCES}

1. Dambo. Effects of exposing aquatic organisms to crude and refined water soluble oils. Tropical Journal of Zoology. 1999;19:213-219.

2. Ogundiran MA, Fawole OO, Adewoye SO, Ayandiran TA. Pathologic lesions in the gills of Clarias gariepinus exposed to sublethal consecrations of soaps and detergent effluent. Journal on cell and Animal Biology. 2009;3(5):078 -082.

3. Abbas $\mathrm{HHH}$, Mahmood HM. The toxicological effect of water pollution on the Nile Tilapia fish (Oreochromis niloticus and Clarias gariepinus) exposed to mixtures of copper and salts. Egyptian Journal of Basic \& Applied Physiology. 2003;3:89-106.

4. Ivon, Ndome. Comparative effects of detergents and liquiod soaps on the African catfish (Clarias gariepinus) fingerlings in Calabar, Nigeria. Asian Journal of Biology. 2016;2(4):12-19.

5. Esenowo IK, Ugwumba DA. Growth response of catfish (Clarias gariepinus) exposed to water solube fraction of detergent and diesel oil, Environment Research Journal. 2010;4(4):298-301.

6. Adewoye, Lateef A. Evaluation of the microbiological characteristics of Oyun River-A polluted river in North-central. Pollution Research. 2004;23(14):587-591.

7. Adewoye SO, Fawole OO, Owolabi OD, Omotosho JS. Toxicity of cassava wastewater effluents to African catfish: Clarias gariepinus. Ethiopian Journal of Science. 2005;28(7):189-194. 
8. Adham KG, Hamed SS, Ibrahim HM, Saleh RA. Impaired functions of Nile Tilapia, Oreochromis niloticus from polluted waters. Ada Hydmchemical et Hydrobiological J. 2002;39(1):21-28.

9. Ivon EA, Etangetuk NA, Ubi GM, Anyanwu CO, Nkang AN, Ekanem AP. Assessment of histopathological damages in African Catfish (Clarias gariepinus) as influenced by Nittol Detergent Aquatic Pollution in Nigeria. Annual Research \& Review in Biology. 2020;1-11.

10. Aguiwo JN. The toxic effects of cymbush pesticides on growth and survival of African catfish, Clarias gariepinus (Bchell, 1822). Journal of Aquatic Science. 2002; 77(2):81-84.

11. Udeaja O. Goodness. Effect of petroleum by products (Kerosene and fuel) on the hematology of African catfish (Clarias gariepinus). Th Environmentalist. 2016;2(15):25-36.

12. Akhtar $\mathrm{MH}$. The deposition of $\mathrm{I4C}$ agrochemical residues in plants and animals tissue when consumed by animals. In T. Green halgh and T. R. Roberts (Eds.), Pesticide Science and Biotechnology. Ottawa: Proceedings Chemistry. 1986;10-15.

13. Anastacio PM, Holten-Lutzhoft HC, Hailing-Sorensen B, Marques JC. Surfactant (Genapol OX-80), toxicity to Selenastrum capricornulum. Chemosphere. 2000;40:835 838.

14. Anderson T, Forlin L, Hardig J, Larsson A. Physiological disturbances in fish living in coastal water polluted with bleached kraft pulp mill effluents. Canadian Journal of Fisheries Aquatic Science. 1988;45:15251536.

15. Bucher P, Hofer R. The effects of treated domestics' sewage on three organs (gills, kidney, liver) of brown trout (Salmo irutta). Water Research. 1994;27:255-26.

16. Antonio FF, Jorge VFC, Sofia GS, Sandra MM, Joao C, Pedro M, Antonio FF. Histopathological changes in liver and gills epithelium of Nile tilapia, Oreochromis niloticus, exposed to waterborne copper. Pesq. Vet. Bras. Marco. 2007;27(3):103109.

17. Avoajah DA, Oti EE. Effect of sub-lethal concentration of some pesticides on the growth and survival of the fingerlings of the African freshwater catfish: Heteroclarias (Hybrid fingerlings) Nigeria Journal of Biotechnology. 1997;8:40-45.
18. George RO. Acute toxicity effects of Quo Iboe Crude on the gills of Clarias gariepinus juveniles. Asian Journal of Biology. 2012;1(3):34-40.

19. Ayoola SO. Histopathological effects of glyphosate on Juvenile African catfish (Clarias gariepinus) Ameri-surasian Journal of Agricultural and Environmental Science. 2008;4(3):362-367.

20. Adewoye SO, Favwole OO. Acute toxity of soap and detergent effluent to fresh water. Clarias gariepinus fingerlings. African $\mathrm{J}$. Sc. In press). 2002;20(5):22-35.

21. Capkins, et al. Study on the sub chronic toxicity of composite inorganic fertilizers such as Ammonium sulfate on the skin, liver, gills, pancrease, kidney of Juvenile Rainbow trout fish (onchorhyn chusmykiss). Tropical Journal of Zoology. 2009;19:180-188.

22. Adewoye SO, Fawole OO, Owolabi OD, Omotosho JS. Toxicity of cassava wastewater effluents to African catfish (Clarias gariepinus) Ethopian Journal of Science. 2005;28(7):189-194.

23. Adham KO, Hamed S, Ibrahim HM, Saleh RA. Impacted functions of Nile Tilapia, Orechromis niloticus from pulluted waters. Acta Hydrochemical et Hydrobiological. Indian Journal of Quaculture. 2002;16(2): 77-80.

24. Isyaku B, Solomon JR. Effects of detergents and the growth of the African catfish Clarias gariepinus). Tropical Journal of Zoology. 2016;19:198-204.

25. Aghoghovwia OA. Toxicity of detergent to the Aquatic environment. First edition, Nixon Publishers. 2015;12-13.

26. Aguiwo JN. The toxic effects of cymbush pesticides on growth and survival of African catfish, Clarias gariepinus (Behell 1822). Journal of Aquatic Science. 2002; 17(2):81-84.

27. Andem AB, Odey $\mathrm{CO}$, Esenowo Ime, Inyang Inimfon. Ecological approach of plankton responses to water quality variables of a tropical River, SouthEastern Nigeria: A Bioindicator base of community Assessment of Idundu River. Asian Journal of Fisheries and Aquaculture. 2019;3(1):1-17.

28. Byne P, Speare D, Ferguson HW. Effects of cationic detergents on the gills and blood chemistry of rainbow traut. Salmo Gaurdner. 1989;6:185-196.

29. Canli M, Kargin F. A comparative study on heavy metals $(\mathrm{Cu}, \mathrm{Cr}$. $\mathrm{Pb}$ and $\mathrm{Ni})$ 
accumulates in the tissue of Carp. Cyprinus carpio and Nile fish. Tilapia niloticus. Tropical Journal of Zoology. 1995;19:165-171.

30. Boughlenger, David, Turgel, Hogedoorn. A textbook on Characterization of the African Catfish. 1980;25-36.

31. Ekanem AP, Oscar M. Effects of detergents on the behavioural responses of Clarias gariepnus sub adult in Calabar, Nigeria. Asian Journal of Fisheries and Aquaculture. 2004;2(4):23-26.

32. Abel PD. Toxicity of synthetic detergents to fish and aquatic invertebrates. 2006;6 (3):279-298.

33. Adams SM, Shephard KL, Greeley MS, Jr. Jimenez BD, Ryon MG, Shugart LR, McCarthy JF. The use of bioindicators for assessing the effects of pollutant stress on fish. Marine Environmental Research. 1989;28:459-464.

34. Adewaye. Comparative study on the behavioural responses of Clarias gariepinus fingerlings on exposure to soaps and detergents effluents. 2010;1: 89-95.

35. Ekanem AP, Ekpo AL. Effects of commerical detergent on the juveniles of Heterbranchus longifills (Curvier and Valiennees). African Journal of Environmental Pollution and Health. 2006;6(1):18-23.

36. Ekanem AP. Anatomy and physiology of the African catfish (Clarias gariepinus) Adults. African Journal of Marine Sciences. 2012;8(1):10-23.

37. Environmental protection Agency. Chemical limits and standards in theaquatic Ecosystem. 2011;45-60.

38. Ewa-Oboho O. Amu. Effectis of crude oil extracts on early stages of African catfish heterobranchus longifilis (VAL) reared under controoled condition. Global Journal on Environmental Sciences. 2009;8(2):3041.

39. Farkas A. Salanki, J, Speeziar. Relation between growth and the heavy metals concentration in organs of bream, Abramis brama L., populating late Blaton. Archive of Environmental Contaminants and Toxicology. 2007;43(2):236-243.

40. Francis EA, Ita-Ewa Oboho Paul J. Udo, Ekaete F. Asuquo. Fish species used as biomakers for heavy metals and hydrocarbon contamination for Cross River State, Nigeria. Environmentalist. 2006;8 (2):30- 41
41. Geetanjali, Choudhavy and Iha. Influence of household detergents on some serum biochemical parameters of fresh water fish, chanapuntatus. Asian Journal of Biotechnology. 2013;21(3):121-123.

42. Govind PO. Effects of Linear Alkyl Benzene Sulfonate on the gills structure of the African catfish (Clarias gariepinus). Environment Research Journal. 2014;4 (4):288-301.

43. Health, Benneth. Hematological and histopathological changes of C. gariepinus adults exposed to petroleum product. Journal for Environment and Toxicology. 1990;5(4):20-25

44. Holzloenher. A textbook on wetlands and coastal zones in Calabar, First editon. 2002;40-45.

45. Lenntech. Bulletins detergent occuring in fresh water. Rotterdamsewg: Lenntech BV. 2012;6:123.

46. Morah FN. Advanced organic chemistry, $3^{\text {rd }}$ edition. 2012;158.

47. National Population Commission. Statistical update on the Nigerian population in Nigeria, 2016 edition. 2005;20:12-13.

48. Ndome C, Mowang DA, Ayibaerai TT. Comparative acute toxicity of local detergents (Omo and Ariel) on fingerlings of the Clarias gariepinus Heterbranchus longifillsc hybrid, AACL Bioflux. 2013;6 (4):413-420.

49. Ogundiran MA, Fawole OO, Adewoye SO. Effects of soap and detergent effluents on the haematological profiles of Clarias gariepinus, Science Focus. 2007;12(1): 84-88.

50. Omoregie F, Ufodike FBC, Keke IR. Tissues chemistry of $\mathrm{O}$. niloticus exposed to sub lethal concentration of gammalin 20 and actellic 251EC. Journal of Aquatic Science. 1990;5:33-36.

51. Preeti B, Sexena M. Evaluation of lethal concentration of fertilizer (NPK) to fresh water fish, mystus vitatus. River State Environmental Protection Agency, (1992). Animal Environment reports; 2016.

52. Abdel-Moneim AM. Froese (2014). Behaviour, Habitat and Characteristics of the African catfish (Clarias gariepinus). $2^{\text {nd }}$ edition. 2005;3-5.

53. Abel PD. Toxicity of synthetic detergents to fish and aquatic invertebrates. 2006;6 (3):279-298.

54. Ogundele O, Ihuahi JA, Omojowo FS, Bitrus P. Toxicity of linear alkybenene 
sulphonate (LAS) detergent, to Claria gariepinus fingerlings. In 19th Annual Conference of the Fisheries Society of Nigeria (FISON), 29 ${ }^{\text {th }}$ Nov. 03 Dec. 2004, llorin, Nigeria. 2005;271-276.

55. Ogundiran MA, Fawole GO, Adewoye SO, Ayandiran TA. Toxicological impact of detergent effluent on juvenile of African catfish (Claria gariepinus) (Bushell 1822), Agriculture and Biology Journal of North America. 2010;1(3):330 -342.

56. Adams SM, Shephard KL, Greeley MS Jr. Jimenez BD, Ryon MG, Shugart LR, McCarth JF. The use of bioindicators for assessing the effects of pollutant stress on fish. Marine Environmental Research. 1989;28:459-464.

57. Adewaye AO. Comparative study on the behavioural responses of Clarias gariepinus fingerlings on exposure to soaps and detergent effluents. 2010;1: 8995.

58. Adewoye, Lateef. Evaluation of the microbial characteristics of the Oyun River- A polluted river in North-Central Nigeria. Pollution Research. 2004;23(14): 587-591.

59. Sangeetha DF. Acute toxicity of ammonium sulphate and composite fertilizer NKP 15:15:15 on the African catfish fingerlings; 2011.

60. Ivon EA, Etangetuk NA, Ubi GM, Anyanwu CO, Nkang NA, Ekanem AP. Assessment of histopathological damages in African catfish (Clarias gariepinus) as influenced by Nittol Detergent Aquatic Pollution in Nigeria. Annual Research and Review in Biology. 2020;35(4):1-11.

(c) 2020 Ivon et al.; This is an Open Access article distributed under the terms of the Creative Commons Attribution License (http://creativecommons.org/licenses/by/4.0), which permits unrestricted use, distribution, and reproduction in any medium, provided the original work is properly cited.

Peer-review history:

The peer review history for this paper can be accessed here: http://www.sdiarticle4.com/review-history/57597 